Article

\title{
Sustainability Strategy and Management Control Systems in Family Firms. Evidence from a Case Study
}

\author{
Fabio Caputo ${ }^{1}$, Stefania Veltri ${ }^{2, *}$ and Andrea Venturelli ${ }^{1}$ \\ 1 Department of Management, Economics, Mathematics and Statistics, University of Salento, \\ Via per Monteroni, 73100 Lecce, Italy; fabio.caputo@unisalento.it (F.C.); \\ andrea.venturelli@unisalento.it (A.V.) \\ 2 Department of Business Administration and Law, University of Calabria, Ponte P. Bucci, \\ 87036 Arcavacata di Rende (CS), Italy \\ * Correspondence: stefania.veltri@unical.it; Tel.: +39-0984-492126
}

Academic Editor: Barbara Aquilani

Received: 23 March 2017; Accepted: 5 June 2017; Published: 7 June 2017

\begin{abstract}
The aim of this paper is to investigate how the integration of new forms of sustainable control systems (SCSs) and traditional management control systems (MCSs), and the use of these control systems affect the integration of sustainability within organizational strategy. A qualitative case study based on a longitudinal investigation of an Italian family firm operating in an environment-sensitive context, the intermodal transport industry, has been used to trace the company's pathway to sustainability integration based on the Gond et al. framework. The paper enriches the Gond et al. conceptualization providing evidence of the external and internal factors relevant in affecting the organization's pathway towards sustainability integration. To the best of the authors' knowledge, the present study is the first analysis that investigates the integration of sustainability into organizational strategy in the context of family firms, from the point of view of performance management systems (PMSs).
\end{abstract}

Keywords: management control systems (MCSs); sustainability control systems (SCSs); performance management systems (PMSs); sustainability integration; Family firm; case study; Italian territory; intermodal transport

\section{Introduction}

The last few decades have witnessed increasing pressures for organizations to behave in a socially and environmentally responsible fashion, and businesses have started to acknowledge the importance of sustainability, embracing the sustainability rhetoric in their external reporting and in their mission statement [1-4].

To define sustainability, we refer to Dyllick and Hockerts, who defined sustainability as "meeting the needs of a firm's direct and indirect stakeholders without compromising its ability to meet the needs of future stakeholders as well"; to achieve this goal, companies need "to maintain their economic, social and environmental capital base" [5]. This definition is an application at corporate level of the definition of sustainable development given by the World Commission on Environment and Development (WCED), according to which a sustainable development is a "development that meets the needs of the present without compromising the ability of future generations to meet their own needs" [6]. In the article, consistently with other researchers [3,4], the term sustainability will be used interchangeably with the term Corporate Social Responsibility (CSR), definable as "a concept whereby companies integrate social and environmental concerns in their business operations and in their interaction with their stakeholders on a voluntary basis" [7]. 
Consistently with a stream of the literature [7-9], we believe that, although sustainability and CSR have evolved from different histories, they are pushing toward a common future. They both share the same vision, which intends to balance economic responsibilities with social and environmental ones and they both have their theoretical roots in stakeholder theory. According to this theory, organizations have obligations not only to shareholders but also to other interest groups (stakeholders) such as customers, employees, suppliers and the wider community, amongst many others $[8,10]$ (Note 1 , Appendix A).

Sustainability management accounting research has attracted increasing scholarly attention with a focus on external reporting [11], whereas only a limited consideration has been dedicated to the role of management controls in supporting sustainability within organizations [1] (Note 2, Appendix A). In other words, much has been written about "why" companies are involved in sustainability issues, such as the determinants of sustainability reporting and factors leading to the implementation of sustainability practices $[12,13]$, while relatively little research has addressed the "how" question such as how companies integrate sustainability into corporate performance management systems (PMSs) [14] (Note 3, Appendix A).

Recently, some articles have stressed the importance of integrating sustainability within PMSs and have studied the development, the structure and the use of specific sustainability control systems (SCSs) [1,10,15-20]. Sustainability could definitely be a driver for corporate success [21], but organizations need to integrate sustainability into corporate strategy and corporate PMSs. On the other hand, it should be underlined that integrating sustainability within organizational strategy is not an easy task, since it requires the alignment of several interrelated technical, organizational and cognitive aspects.

A recent article [1] proposed a research framework that openly considers and delineates a set of possible relationships between sustainability issues, firms control systems and organizational strategy. The Gond et al. framework [1] identifies eight different sustainability strategies, given by the different (diagnostic or interactive) use and the integration of management control systems (MCSs) and sustainability control systems (SCSs). The Gond et al. framework has recently been applied to an oil and gas company [22] and an Italian co-operative [23], and we also choose to apply this framework to a case study of an Italian family firm operating in an environment-sensitive industry (the intermodal transport industry).

The aim of the study is to investigate the integrative how question, particularly how the integration of the new forms of SCSs and traditional MCSs and the (diagnostic or interactive) use of MCSs and SCSs affect the integration of sustainability within organizational strategy. A qualitative case study based on a longitudinal investigation of an Italian family firm operating in an environment-sensitive context has been used to trace the company's pathway to sustainability integration based on the Gond et al. framework [1].

To the best of the authors' knowledge, the present study is the first analysis that investigates the integration of sustainability into organizational strategy in the context of family firms, from the internal point of view of the interplay of the corporate control systems.

Family firms are an interesting empirical setting to study sustainability issues because there are strong theoretical and empirical reasons to argue that family involvement in the business can affect their attitude towards sustainability issues [24].

The paper enriches the Gond et al. theoretical conceptualization by analyzing the path towards sustainability of a family business. In doing so, the study also sheds lights on the external and internal factors affecting the sustainability integration pathway.

\section{Literature Review}

The paper aims to investigate the relationship between sustainability strategy and control systems in family firms, therefore the section briefly illustrates two streams of literature, the first focused 
on the issue of sustainability and CSR within family firms, the second focused on empirical studies investigating the integration of sustainability issues within corporate management and control systems.

\subsection{Literature Review of Sustainability/CSR and Family Firms}

Scholars have only recently studied the issue of corporate social responsibility (CSR) in the field of family business. Although both the theoretical and empirical definition of the family firm have been the subject of considerable debate, a defining characteristic of family firms is the centrality of family control and involvement in firm decision-making [25]. Family firms exist at the intersection of two system, the family and the business, and this dual identity, named as familiness, is the feature that characterizes the research on family firms [26], as the organizational outcomes are the product of the interaction between family and business.

Existing theoretical and empirical research on the diffusion of social responsibility in family firms has largely focused on the differences in terms of CSR among family and non-family firms [27]. Among this category of studies, the study of Adams et al. [28] does not succeed in providing evidence of different ethical behavior of family versus non-family firms, but it highlights how different family firms' characteristics affect their business ethics and ultimately their behavior towards stakeholders. In addition, Hirigoyen and Poulain-Rehm [29] and Dyer and Whetten [30] do not succeed in providing evidence of different behavior of family firms towards their stakeholders. Dyer and Whetten [30] found that family firms are more attentive to their reputation and more likely to be viewed as legitimate by their local community. Berrone et al. [31] also found that family firms are more compliant in respecting environmental standards than their counterparts, and relate this to the desire of family firms to preserve their socio-emotional wealth, which is a non-economic utility complementary to economic wealth $[32,33]$.

Another literature stream focused instead on the differences in CSR orientation, behavior, practices, attitude towards stakeholders, and performance among family firms. Déniz and Suarez [34] highlight the heterogeneity of CSR behavior in different types of family firms, Niehm et al. [35] emphasize the values of family owners on CSR behavior; while Uhlaner et al. [36] show that family involvement in the business affect the relationships with family firms' stakeholders. Ding and $\mathrm{Wu}$ [37] found a difference between newer family firms, less interested in their reputation and preservation of their socio-emotional wealth in comparison with their more mature counterparts. McGuire et al. [38] highlight a link between familiness and social performance, while Bergamaschi and Randerson [27] classify family firms as regards their different approach towards CSR. Campopiano and De Massis [39], investigating the CSR reports of 98 large- and medium-sized Italian firms show that, in comparison to nonfamily firms, family firms disseminate a greater variety of CSR reports, are less compliant with CSR standards and place emphasis on different CSR topics. Finally, Le Breton-Miller and Miller [40] highlight the factors that could drive family firms towards a positive or negative attitude towards corporate sustainability practices, i.e., the tendency to behave in economically, socially and environmentally responsible way in a manner that benefits all stakeholders and the entire community.

Summarizing, from these studies it emerges that family firms are more prone to preserve their reputation, to be legitimized by their stakeholders and to preserve their socio-emotional wealth, but it also emerges that family firms are far from being a homogenous sector, even in their approach to CSR [41]. This leaves room for research carried out through case studies, which could be, if used rigorously, a valuable method for generating a richer, deeper understanding of family business. Sustainability is a social object and, in order to be understood, it has to be "contextualized" [42]. The case study methodology is particularly suitable for exploring practices related to the sustainability issues from an inside-out perspective, since they are firm-specific and context-specific. Despite case studies having been the most used methodology in family firms' research to date [43], they have scarcely been employed in investigating the approach towards CSR [44]. This is because the existing research has been focused on case studies of large or small and medium-sized enterprises (SMEs) without specifying their family nature $[18,45]$. 


\subsection{Literature Review of Sustainability and Corporate Management Control Systems}

A recent trend in the sustainability literature shifted attention from the question of why companies should attend to sustainability issues to how sustainability issues could be integrated into organizational systems and processes [13,46,47].

Focusing on internal organizational processes means exploring the role of corporate control systems in the integration of sustainability within the organizational strategy. In turn, corporate control systems, or in a wider sense corporate PMSs, should include all aspects of organizational control [48]. With organizational control, we mean both control related to the Management Control Systems (MCSs), and control related to the Sustainability Control Systems (SCSs), an extension of traditional MCSs. In detail, the control related to MCSs aims to ensure that all processes and activities of an organization are aligned to the organizational strategies and objectives [35], while control related to SCSs aims to address the interrelationships between economic, environmental and social issues related to organizational performance [48] (Note 4, Appendix A).

In management control literature, researchers have been increasingly interested in sustainability issues focused on how traditional MCSs could be used to integrate sustainability goals into organizational strategy $[49,50]$. Other studies focused instead on specific single sustainability control tools, aimed to align sustainability strategy with MCSs [48], such as a sustainability balanced scorecard [51], dartboards of sustainability [52], a corporate sustainability performance pyramid [53], sustainability/environmental budgeting [54], material and energy flow cost accounting systems [55], eco-controls [56], and a sustainability report [57,58]. Nevertheless, this literature stream has two main limits. Firstly, most of these studies are focused on environmental sustainability only [56,59]. Secondly, this research generally proposed and examined only SCSs, paying little attention to the interplay of SCSs with the more traditional MCSs [1,60].

Nevertheless, some studies started to stress not only the importance of relying on SCSs in forming or supporting sustainability strategy, but also to integrate specific SCSs with the traditional corporate MCSs, to be sure that business operations are run in accordance with sustainable goals $[1,61]$.

Our paper aims to address the call for more research on how the interaction of the new forms of SCSs and traditional MCSs and the use of these control systems affect sustainability integration within organizational strategy by employing the Gond et al. framework [1]. Such a model, which is the first accurate model to delineate a set of possible relationships between sustainability issues, corporate control systems and organizational strategy, has also been employed in two recent case studies [22,23]. We decided to use the Gond et al. framework [1] in an Italian family firm.

However, there has been limited research specifically focusing on the enablers of, and barriers to, sustainability integration in PMSs (Note 5, Appendix A). In addition, it is undeniable that the operating environment affects the organization's movement from one configuration to another, and an analysis focused on sustainability integration within an organization should consider the operating environment in terms of institutional pressures [22].

Our conceptualization of the Gond et al. [1] framework took into consideration these concerns by shedding light both on the enablers and barriers to sustainability integration in the PMSs of the GTS Group and on the external factors which affected the organization's movement from one configuration to the next. Moreover, in the paper, we carried out a longitudinal analysis, thereby responding to Gond and coworkers' [1] call for extended studies aimed at empirically investigating organizational transformation concerning sustainability integration. The following sections are thus devoted to illustrating the Gond et al. framework [1], the case study methodology and the family firm selected to address the how research question, before presenting the findings in terms of organizational configurations as in the Gond et al. framework [1]. The enablers and barriers to sustainability integration of PMSs and the external factors which affected the GTS Group organizational configurations will be separately illustrated. 


\section{The Research Framework}

To explain the movement of the case organization through different stages of the sustainability integration process, we employed the Gond et al. framework [1]. This framework, analyzing the corporate MCSs and SCSs under two profiles, the use of both MCSs and SCSs-diagnostic vs. interactive-as well as their level of integration on three dimensions (technical, organizational and cognitive) delineates eight ideal-types of sustainability strategies configurations: dormant decoupled strategy (Configuration A); strategy emergence through sustainability (Configuration B); compliance driven sustainability strategy (Configuration C); schizoid sustainability strategy (Configuration D), dormant integrated strategy (Configuration E); sustainability driven strategy (Configuration F); peripheral sustainability integration (Configuration G); and integrated sustainability strategy (Configuration $\mathrm{H}$ ).

Figure 1 graphically summarizes these eight ideal-types of organizational configurations.

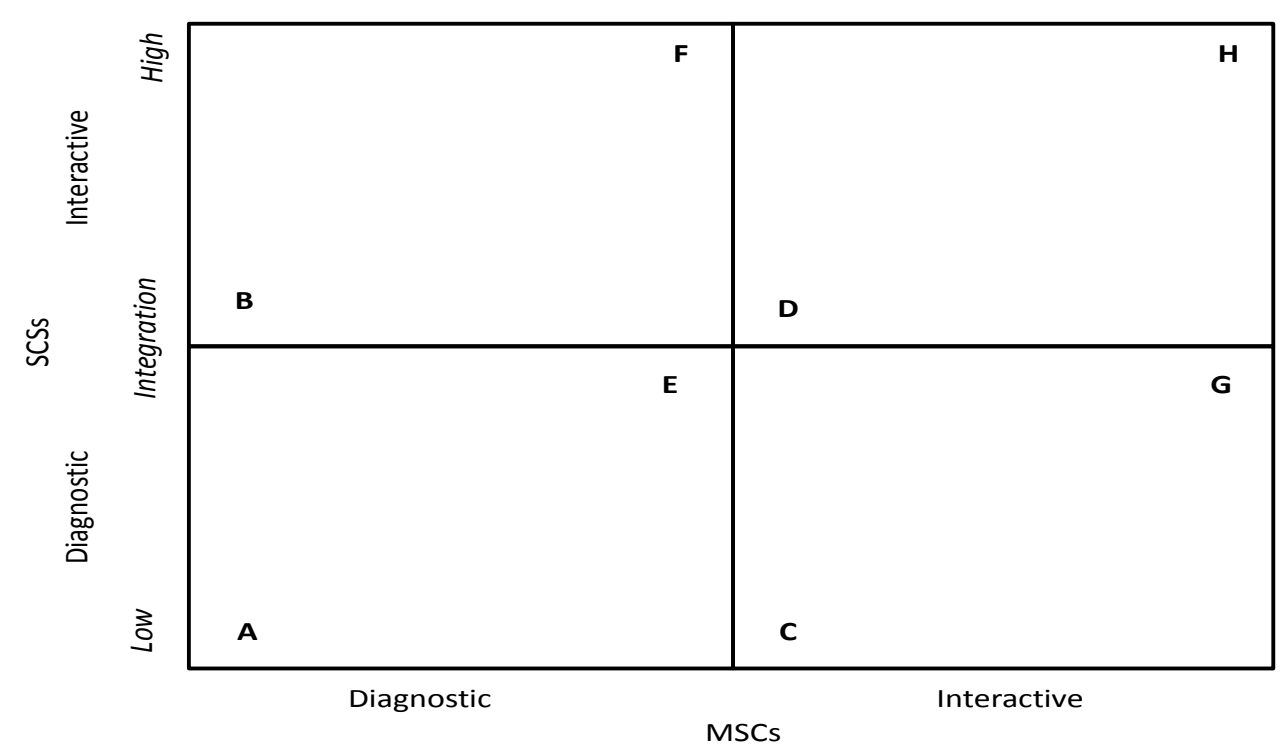

Figure 1. Graphical representation of sustainability integration strategies.

Corporate control systems can be used in a diagnostic or interactive way [62]. Simons [62] gives this attribute to the corporate control systems in relation to their contribution to strategy-making process. Thus, diagnostic control systems are tools that help in formulating and achieving organizational intended strategies, while interactive control systems are tools that stimulate and guide emergent strategies in response to opportunities and/or threats within an organization's operating environment. When top managers decide to use a tool in an interactive way, they require the employees to be involved in the analysis of environmental uncertainty and in an attempt to learn novel strategic responses to a changing environment. Interactive systems are more challenging to apply, as they require intensive dialogue and frequent personal interactions between top managers and subordinates. Therefore, the control tools (both MCSs and SCSs) could be used by managers to control and correct the actors' actions (diagnostic) or as strategic levers to support changes aligned with strategic objectives (interactive). In other words, control systems could be used to implement strategies (diagnostic) or form new strategies (interactive).

Nevertheless, SCSs can contribute to an effective integration of sustainability within strategy only when they inform MCSs and are not used as "autonomous strategic tools" [62]. Instead, if SCSs remain peripheral and decoupled from core business activities, they fail to reshape organizational strategy to integrate sustainability. In order to achieve this aim, not only MCSs and SCSs should be used interactively, but also the integration of the two kinds of corporate control system (MCSs and 
SCSs) is needed. The integration of MCSs and SCSs is a difficult task that encompasses organizational, cognitive and technical dimensions [1].

Technical integration is the integration of existing SCSs with formal MCSs and activities. It involves the examination of how existing MCSs are used in relation to sustainability. Analysis of technical integration thus involves the examination of methodological links between systems used for traditional and sustainability performance, such as the presence of a common infrastructure to gather information for both systems.

Organizational integration refers to how actors and processes are organized around sustainability. The central assumption is that sustainability issues can be adequately managed and measured only if the roles and formal structure of organizations are established in a way that facilitates an analysis and discussion of these topics among all the staff [23].

Finally, cognitive integration refers to what people think of sustainability. It requires knowledge that is exchanged and assimilated by the respective individuals own knowledge structures. In organizational contexts characterized by high levels of integration, MCSs and SCSs are tightly coupled, whereas in low integration contexts they are only loosely coupled (decoupled).

Table 1 illustrates the eight ideal-types of organizational configurations derived combining the use (use diagnostic vs. interactive) and the integration of MCSs and SCSs (low vs. high).

Table 1. The eight Gond et al. organizational configurations.

\begin{tabular}{|c|c|c|c|c|c|}
\hline \multicolumn{3}{|c|}{ Organizational Configuration } & \multirow{2}{*}{$\begin{array}{c}\text { Integration } \\
\text { Level of } \\
\text { Integration of } \\
\text { MCSs and SCSs }\end{array}$} & \multicolumn{2}{|c|}{ Use } \\
\hline Type & Label & Main Characteristics & & Use of MCSs & Use of SCSs \\
\hline A & $\begin{array}{l}\text { Dormant decoupled } \\
\text { strategy }\end{array}$ & $\begin{array}{l}\text { Parallel systems of control for } \\
\text { management and sustainability }\end{array}$ & Low & Diagnostic & Diagnostic \\
\hline B & $\begin{array}{l}\text { Strategy emergence } \\
\text { through } \\
\text { sustainability }\end{array}$ & $\begin{array}{c}\text { MCSs and SCSs are not integrated } \\
\text { but SCSs are used by top } \\
\text { managers to deploy a } \\
\text { sustainability strategy }\end{array}$ & Low & Diagnostic & Interactive \\
\hline $\mathrm{C}$ & $\begin{array}{l}\text { Compliance driven } \\
\text { sustainability } \\
\text { strategy }\end{array}$ & $\begin{array}{c}\text { One of MCSs is activated for } \\
\text { strategy development. } \\
\text { Sustainability issues are managed } \\
\text { by a system parallel to MCSs }\end{array}$ & Low & Interactive & Diagnostic \\
\hline $\mathrm{D}$ & $\begin{array}{l}\text { Schizoid } \\
\text { sustainability } \\
\text { strategy }\end{array}$ & $\begin{array}{l}\text { Contradictory sustainability } \\
\text { strategies and traditional } \\
\text { strategies are deployed through } \\
\text { parallel MCSs and SCSs }\end{array}$ & Low & Interactive & Interactive \\
\hline $\mathrm{E}$ & $\begin{array}{l}\text { Dormant integrated } \\
\text { strategy }\end{array}$ & $\begin{array}{l}\text { Similar to A, but it is more } \\
\text { probable to move towards } \\
\text { integrating sustainability for the } \\
\text { potential interactive engagement } \\
\text { with one of the two systems }\end{array}$ & High & Diagnostic & Diagnostic \\
\hline $\mathrm{F}$ & $\begin{array}{l}\text { Sustainability-driven } \\
\text { organizational } \\
\text { strategy }\end{array}$ & $\begin{array}{l}\text { MCS are not used interactively. } \\
\text { The sustainability-driven strategy } \\
\text { process is driven by the } \\
\text { interactive use of SCSs }\end{array}$ & High & Diagnostic & Interactive \\
\hline G & $\begin{array}{l}\text { Peripheral } \\
\text { sustainability } \\
\text { integration }\end{array}$ & $\begin{array}{l}\text { MCSs are used interactively, while } \\
\text { SCSs are used as diagnostic tools }\end{array}$ & High & Interactive & Diagnostic \\
\hline $\mathrm{H}$ & $\begin{array}{l}\text { Integrated } \\
\text { sustainability } \\
\text { strategy }\end{array}$ & $\begin{array}{c}\text { Sustainability strategy is } \\
\text { deployed and renewed though } \\
\text { the use of coherently integrated } \\
\text { MCSs and SCSs }\end{array}$ & High & Interactive & Interactive \\
\hline
\end{tabular}

Source: authors' original elaboration based on the Gond et al. framework [1].

These configurations indicate different modes of managing, monitoring and controlling sustainability. Moreover, the Gond et al. framework [1] should be used with a longitudinal approach: due to the changing nature of integration reflected by changes in the use of control systems, a firm may 
explore different path towards sustainability integration or towards sustainability marginalization (Figure 2).

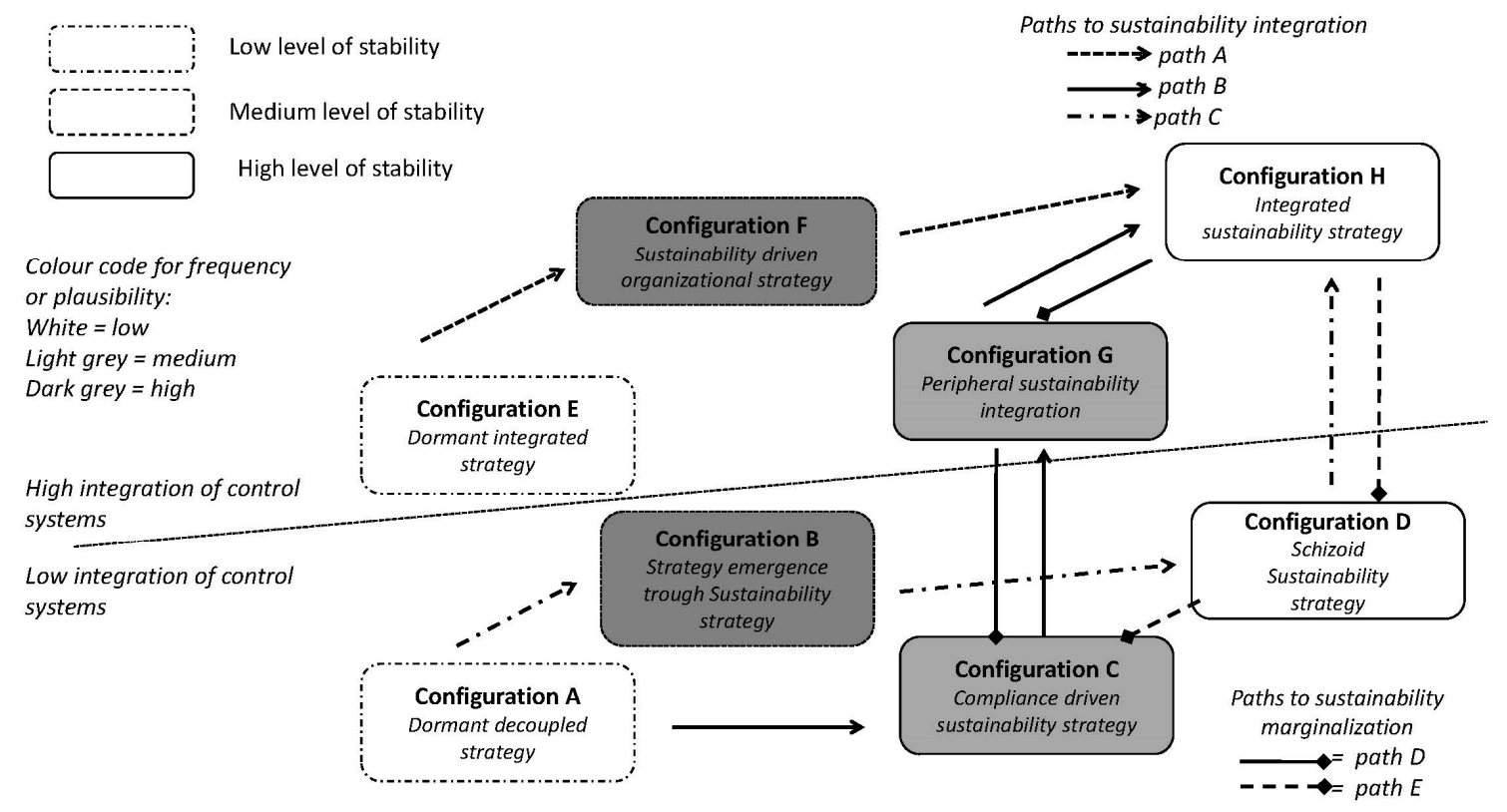

Figure 2. Exploring paths to sustainability integration and sustainability marginalization.

Summarizing, Paths A, B and C are examples of possible paths to an integrated sustainable strategy (Configuration $\mathrm{H}$ ), while Paths $\mathrm{D}$ and $\mathrm{E}$ highlight the path of sustainability marginalization from an integrated sustainable strategy to a compliance-driven sustainability strategy (Configuration C). Figure 2 also highlights the frequency (low, medium, and high) and stability (low, medium, and high) of each organizational configuration.

\section{Methodology}

The research was carried out using a qualitative approach. The qualitative tradition in management accounting research literature is a long one, embracing more than 40 years of published accounting literature, but, in many accounting research communities, it still suffers marginalization. This is also the case of the case study methodology, which plays a particularly important role among qualitative methods [63]. Instead, qualitative orientation offers particular value at the organization-specific level; it is at this level that most managers and management accountants make decisions and act; it is at this highly contextualized and situationally specific level that they seek policy and practice insights [64-66]. For these reasons, a case study methodology has been used to investigate the issue of the pathway of sustainability integration in a family firm.

The case study method is one of the less used by researchers investigating sustainability integration into business, as emerges from a recent structured literature review [14]. Nevertheless, the same research highlights the potential of a case study approach in promoting the in-depth understanding of the research phenomena under investigation [67-69]. In addressing this call, we would also to underline that, to the best of our knowledge, this paper illustrates the first application of the Gond et al. framework [1] to a family firm.

The organization analyzed is a family firm and case studies have been the most used qualitative methodology in family business research to date [43]. Consistently with De Massis and Kotlar [70], we believe that case study is a powerful methodology for generating a richer and deeper understanding of family business. The inner features of case studies, in fact, could be particularly relevant to family business research because family firms exist at the intersection of two systems, the family and the 
business that interact in producing idiosyncratic organizational outcomes. Family firms, in fact, are characterized by the need to balance the divergent identities, interests, and priorities of members of the family and the business systems, all of which are aspects that are particularly difficult to capture through quantitative methods [70]. Moreover, case studies can be particularly helpful to understand how processes are deployed in family firms, which is an area that has been rather neglected so far, given also their heterogeneous nature [71]. In using a case study, we address the call to researchers to give a practice turn to their researches in sustainability issues by "dirtying their hands" with practical case studies [72].

In detail, the article analyzes a single in-depth case study of a private Italian family firm that followed a path that brought it to the disclosure in 2014 of its first sustainability report. The GTS Group, a southern-Italian family firm operating in the transport industry has been selected. The GTS Group was chosen for several main motives. The first is related to the circumstance that the GTS Group was considered by the researchers to be particularly suitable for illuminating the phenomenon under investigation from an internal point of view (i.e., how the company integrates sustainability into corporate performance measurement, management and control systems) as the case organization was undergoing transformation in the area of sustainability that led in 2014 to the disclosure of its first sustainability report [11]. The second reason is linked to the consideration that sustainability is becoming an increasingly important issue in the sector in which the GTS Group operates, which is intermodal freight transport, characterized by a high production of negative externalities. The third motivation is related to the family nature of the Group, as we would like to understand if "familiness" could affect the GTS Group pathway towards sustainability. Finally, we selected the GTS Group because we have a high level of access to the firm data. We were able to interview the GTS Group managers on multiple occasions during the period of the study, and the GTS Group CEO provided us with extensive archival data relating to the history of the firm.

We used an explorative and a longitudinal case study approach. An explorative case study should be used when the aim is to understand how a phenomenon takes place [70]; it is carried out to acquire useful indications on an area not (or partially not) explored, and its findings constitute just preliminary interpretations of a phenomenon. In the case organization, we use an exploratory case study as our intention was to explore how the sustainability strategy was integrated within the corporate management control systems (Note 6, Appendix A).

Our approach is longitudinal because it explains the movement of the case organization through different stages of the sustainability integration process covering a period going from 2008 to 2014 through the Gond and coworkers' framework [1], which we found suitable to do this. Longitudinal studies are fundamental in assessing sustainability because sustainability integration occurs over a long period of time and the longitudinal analysis responds to Gond and coworkers' [1] call for this kind of studies.

The theoretical paradigm underlying our research is the interpretive model. In the light of interpretivism, sociological phenomena cannot simply be observed but must also be interpreted by the researcher. This means that there is not one absolute reality, but the perspective adopted to interpret the facts generates rather different possibilities [73].

We integrated data collected from a wide range of sources: interviews, historical records, financial data, sustainability data and direct observations with the aim to triangulate (that is to adopt different angles in observing the same phenomenon). It should be highlighted that we chose to use the semi-structured interview because of its high degree of flexibility and because it offers the opportunity to address themes that can come to light during the semi-structured interviews [74].

Data collection was conducted from March 2015 to April 2015. The interview transcriptions, field notes and documentary analysis were coded into key themes (Note 7, Appendix A). Once the material was coded, the findings were reported in chronological order and based on sustainability integration into different aspects of the PMSs. Finally, an analysis of how sustainability integration occurred was done based on barriers and enablers of sustainability integration (from a cognitive, 
organizational and technical perspective) and organizational configurations categorized using the Gond et al. framework [1].

\section{The Selection of the Case Study: The GTS Group}

The GTS Group was chosen as the case characteristics fulfilled the purpose of this study. The GTS Group (the case organization), a family firm organization operating in the intermodal transport, was undergoing transformation in the area of sustainability. The company reported sustainability information, presented itself as socially and environmentally responsible, and had received a number of environmental sustainability-related awards and in 2014 it published its first sustainability report. The GTS Group was thus chosen because the authors had deep access to the firm and because the case offered a distinctive and extraordinary setting in which to observe the phenomenon under investigation.

The GTS Group operated in the European market of railway transport, in the sector of intermodal transport. The GTS Group's sectors of interest were the following (GTS Group Sustainability Report 2014):

- Freight transport services on behalf of third parties in the main European countries;

- Terminal to terminal transport services;

- Arrangement and management of transport and logistics services on behalf of third parties;

- Rail traction services in the Italian and Swiss territory;

- Services of training, management and maintenance of competences in the railway sector; and

- Constructions and management of properties.

The GTS Group structure was made up of seven entities operating in complementary sectors, but as regards the turnover, are created by the two subsidiaries General Transport Services limited company and GTS Group Rail limited company, which respectively deal with intermodal transport and traction services in the freight and passengers sector. The GTS Group, founded in 1977, is in a growth and change phase: a generational managerial succession (from the father to son) is underway and the Group is working in order to be listed to the Italian Stock Exchange (Borsa Italiana) within the next three years. The GTS Group has, in fact, been selected and included in the Borsa Italiana program denominated "Elite". This program supports the best Italian companies aiming to compete in international markets by empowering their industrial, financial and organizing competencies.

\section{Implementing the Semi-Structured Interviews}

Interview guides were prepared informed by the main aim to investigate, that is, to determine how sustainability was integrated into different performance management aspects so as to capture a holistic overview of sustainability integration. We were also interested in how our informants made sense of the interplay between MCSs and SCSs. In addition, interviewees were asked about specific control systems, based on their role in the organization. Observations during site visits, reviews of public documents (i.e., annual reports and sustainability reports), analysis of relevant internal company reports (such as environmental management manuals, stakeholder materiality analysis and Key Performance Indicators (KPI)), and presentations in briefings and seminars by relevant employees enabled the triangulation of data.

Four managers of the main organizational areas of the GTS Group involved within sustainability management and reporting were interviewed, specifically the owner and founder (and also President of the Board of Directors); the CEO, who is the son of the GTS Group founder, the General Director and the Chief Financial Officer (CFO), responsible for coordinating administration, finance and control. Table 2 describes in more details the hierarchical level of the people interviewed at the GTS Group, how many times we interviewed them, the duration of each interview, and the organizational role covered within the GTS Group. 
Table 2. The list of people interviewed at the GTS Group.

\begin{tabular}{ccccc}
\hline Hierarchical Level & $\begin{array}{c}\text { Number of } \\
\text { Interviewees }\end{array}$ & $\begin{array}{c}\text { Number of } \\
\text { Interviews }\end{array}$ & Duration & Role \\
\hline Top management & 3 & 6 (one each) & 6 (one hour each) & $\begin{array}{c}\text { Owner and Founder, Chief Executive } \\
\text { Officer, General Director }\end{array}$ \\
\hline $\begin{array}{c}\text { Middle Level } \\
\text { Manager }\end{array}$ & 1 & 2 & 2 & Chief Financial Officer \\
\hline
\end{tabular}

The semi-structured interviews were carried out from March 2015 to April 2015. Each manager was interviewed individually. Interviews, which lasted one hour each, were conducted to guidelines prepared by the researchers. In order to maintain spontaneity, we let them know the general aim of the research, without disclosing specific questions, to avoid the interviewees pre-preparing answers [75]. At the first interview, in order to establish a good relationship with the interviewees, the researchers introduced themselves and their research before following a preliminary semi-structured interview illustrating the main questions themes (Note 7, Appendix A). The subsequent interviews started following the pre-prepared questions, but leaving to the interviewee the possibility of offering further considerations. It was a precise choice on the part of the interviewers: instead of consisting of questions and predetermined answers, the script was used as a guideline for interactions. The choice of open-ended questions was intended to allow for the interviewees to provide as much information as possible, with the interviewer intervening as little as possible in their answers. It is important to highlight that, before interviewing the GTS Group manager, the script was pretested to identify ambiguous, unclear, and unnecessary questions, and then was reformulated by clarifying some questions and rewriting others. Before closing each interview, it was ensured that all the interview question themes were addressed. The interviews were recorded and transcribed and were supported by notes taken during the interview. The interview data was then broken down and analyzed according to the interview question themes. A qualitative data analysis was applied to the interview data. This allowed researchers to focus on the answers delivered by the respondent in terms of their meaning, while also maintaining sensitivity to the context [76]. A further opportunity to debate on the findings emerged from the qualitative analysis happened during the presentation by the GTS Group of its first sustainability report in May 2015.

Aiming at internal validity, the results of the analyses were also triangulated with other sources of evidence; to give validity to the data analyzed [77]. Triangulation involved the analysis of booklets and other pieces of information on GTS Group on web pages, on the company's homepage, on the organizational reports, on the specific guidelines provided by the GTS Group managers and by other information, financial and non-financial, retrieved mostly on the media.

\section{The Pathway of the GTS Group towards the Integration of Sustainability in Its PMSs}

The pathway of the GTS Group towards the integration of sustainability in its PMSs started in 2008, the year in which the GTS Group rail was founded and it obtained the railway license on the Italian national network. The National Agency for railway safety compelled the GTS Group to respect railway regulation; in respecting it, the GTS Group focused audit activities on risk analysis and process mapping, to keep its safety certificate. In this phase some SCSs tools, aimed to provide sustainability information to address the request of National Agency were introduced, with the aim to address external requirements. They were not used to support internal decision making. The MCSs, composed of the economic and financial budgeting and reporting system, were used to support strategy implementation, and MCSs tools were used by executives as "management by exception" tools in order to correct actors' actions and align activities toward the achievement of corporate objectives. For this reason, MCSs were not able to measure the social and environmental performance and the relationship with the stakeholders (such as suppliers and local communities), because they were focused on measuring the economic and financial performance. The planning and budgeting process in the GTS 
Group did not enable management of social and environmental issues, being addressed to satisfying the strictly internal stakeholders, the employees, without focusing on the external stakeholders of the firm constituting the firm's value chain, that is clients, suppliers, and local community. Following the Waddock (2002) model [78], which identifies three levels of stakeholder involvement: stakeholder mapping (first level), stakeholder management (second level) and stakeholder engagement (third level), we can deduce that the GTS Group involved its stakeholder at the first level, distinguishing between primary and secondary, and managing mainly internal stakeholders' expectations. In this phase, the use of both MCSs and SCSs can be classified as a diagnostic use.

Interpreting data from the semi-structured interviews and the corporate documents, we can say that the integration between these two control systems, the social responsibility actions carried out were not aligned with the business strategy, and they were more an aggregation of uncoordinated actions ineffective both for the most relevant business stakeholders and for the business competitiveness. The GTS Group had a parallel system for the MCSs and SCSs. The diagnostic use of corporate control systems, conjointly with a low integration between MCSs and SCSs, allow us to classify the integration strategy followed by the GTS Group, according to the Gond et al. framework, as a dormant decoupled strategy.

While the dormant decoupled strategy lasted almost three years, but the event that can be considered the starting point of the sustainability project, from a cognitive point of view, was the succession in the GTS Group of the son of the business founder in 2009. From the semi-structured interviews, it emerged that a big impulse to push on sustainability and to prepare the ground for the future sustainability plan for the group is to be ascribed to the vision of the new CEO of the GTS Group. Only when the son of the group founder became CEO, the attitude of the GTS Group towards sustainability issues became explicit. The training path of the CEO and his experiences gained abroad contributed heavily to the process of approaching sustainability issue of the GTS Group, a path that has its roots on the personal convictions and values of the CEO. His persona resembles the features ascribed to a social entrepreneur: a genuine approach towards sustainability, an awareness of the sustainability management tools and he practically supported the implementation of these tools, encouraging the progressive integration of sustainability into organizational strategy. In this situation, anyway, the main organizational barrier for the GTS Group was a lack of organizational structure for sustainability related initiatives, while the main technical barrier was having no systematic infrastructure to measure sustainability performance and no links between the two control systems.

In the period 2011-2013, the GTS Group moved to a different integration sustainability strategy, which in the Gond et al. framework [1] is identified as a compliance driven sustainability strategy, characterized as well by a low integration between MCSs and SCSs, but by an interactive use of MCSs. The event that drove the GTS Group towards an interactive use of MCSs was the GTS Group obtained an extension to the transportation of hazardous goods in 2011. The GTS Group has to guarantee the full monitoring of different phases related to the railway and intermodal transport. To do it, the GTS Group improved its traditional informative system and started to use it in an interactive way, that is, valuing and monitoring environmental risks, so stimulating and guiding emerging strategies in response to opportunities and threats emerging from the GTS operating environment. On the contrary, the parallel SCS continued to be managed diagnostically. In this second phase, however, the GTS Group started to manage stakeholders' expectations balancing different positions (internal and external), so identifying a second level stakeholder engagement. In 2013, the GTS Group used the sustainability information provided by SCSs to be included within the annual report, but the social and environmental information was addressed to satisfying external informational needs and not to decision making purposes.

The period 2014-2015 identifies the strategy configuration named by Gond et al. [1] as peripheral sustainability integration, in which MCSs were still used in an interactive way and SCS in a diagnostic way, but there was a high level of integration between these two corporate control systems. In this period, the GTS group carried out several sustainability initiatives, such as: 
- the definition of ethics code and an organizational model in accordance with the Decree 231/01;

- the OHSAS 18001, ISO 14001 and SA 8000 certifications;

- the allocation of legality ratings;

- the internal and external dissemination of the environmental policy introduced in 2011;

- the definition of a system of delegations regarding sustainability;

- the definition of a risk assessment system and socio-environmental KPI;

- the improvement of the channel of information to customers through the enhancement of the mechanism on the $\mathrm{CO}_{2}$ saving and the formalization of a more efficient claims management system; and

- the establishment of a list of suppliers and the definition of a partner selection process on the basis of criteria related to environment, safety and human rights.

All these initiatives culminated in the disclosure of the first GTS Group sustainability report, for whose drafting an internal work team was created. The attention towards a sustainability report was also fostered by the GTS Group being selected for admission to the program denominated "Elite" as, in order to be listed on the Italian Stock Exchange, the GTS Group had to answer to sustainability requirements.

The input thus come from the external environment, which is an institutional pressure but, to draft the sustainability report, the GTS Group management actively involved the corporate stakeholders.

External stakeholders participated with comments on topics to be discussed, parts to be reported in the sustainability report and dialogue tools to be used through a survey. The survey, applying the materiality principle set out in the GRI-G4 guidelines (used to draft the GTS Group sustainability report), produced a matrix of materiality, included in the GTS Group sustainability report, which cross-checked the level of importance that stakeholders attached to each topic with the relevance of the same topic for the GTS Group. This identifies a third level of stakeholder involvement, namely stakeholder engagement.

The change from socio-environmental information included in the annual report to a sustainability report did not only imply a formal adherence to Global Reporting Initiative (GRI) guidelines, but also a shift to a structure aimed at measuring the social, environmental and economic performance. In such a structure, the strategy in the report is aligned with the corporate business strategy, the management of sustainability issues is linked with the GTS Group family firm socially oriented values and the activities carried out focus on critical dimensions of sustainability for the GTS Group.

Since from the end of 2015, several sustainability initiatives have been implemented. These initiatives implied a shift towards higher technical, organizational and cognitive integration between MCSs and SCSs and an interactive use of SCSs. Beyond the sustainability report, the GTS Group adopted a sustainability plan, with the aim to assess in advance the social, environmental and economic impacts of the initiatives planned on stakeholders. The aim of the annual sustainability plan was to assess in advance the social, environmental and economic impacts of the initiatives planned, while by analyzing the environmental and social performance indicators, the goals and targets of the annual sustainability plan were verified, detailing any failures and the results were communicated to all stakeholders through the sustainability report.

The formulation of a formal sustainability strategy in organizational strategy enables the embedding of sustainability in organizational practices and facilitates the measurement, monitoring, evaluation and achievement of sustainability goals and objectives.

Figure 3 graphically represents the GTS Group pathway towards sustainability integration, the year considered as milestones in the integration process of sustainability within MCSs and SCSs. 


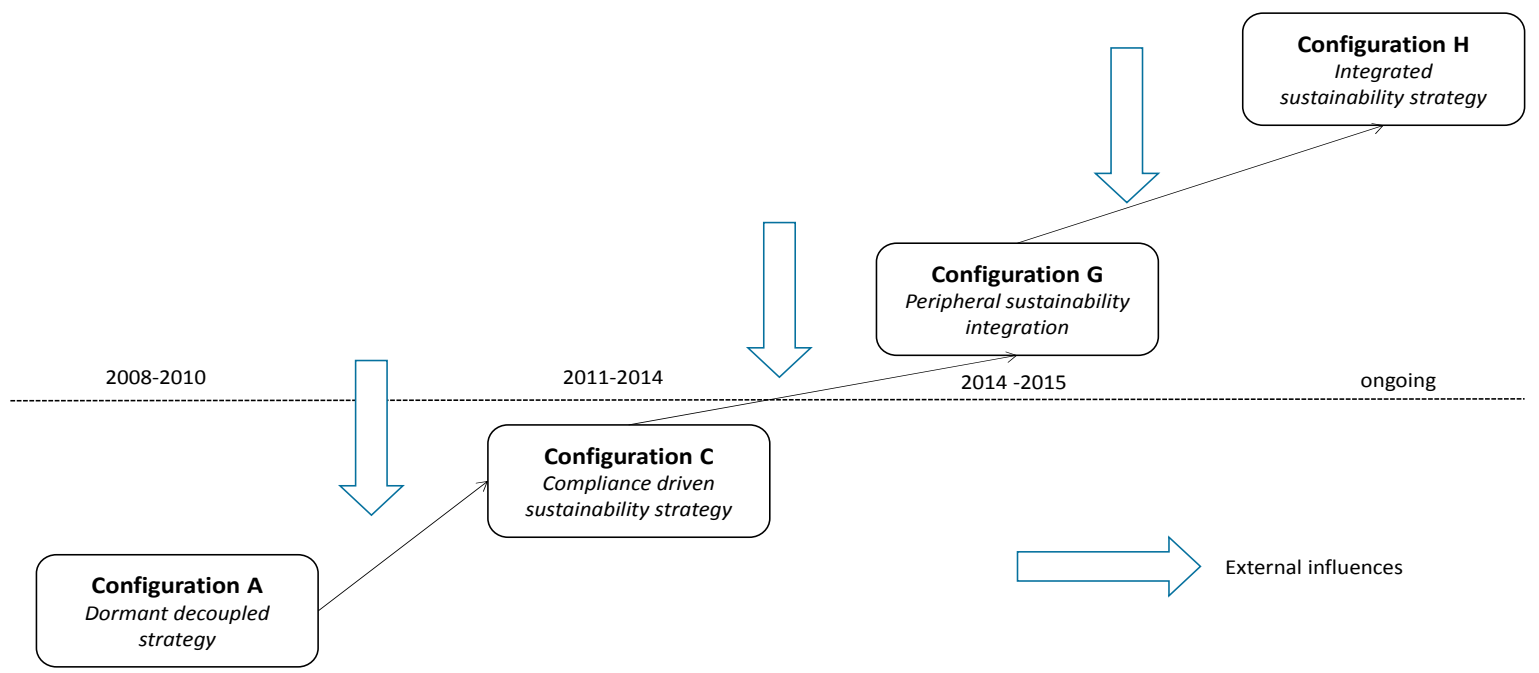

Figure 3. The evolution of sustainability integration in the GTS Group.

The GTS Group pathway to sustainability integration moved from a dormant decoupled strategy (A) to a compliance-driven sustainability strategy (C) and then a peripheral sustainability integration configuration $(G)$. At the time of the research, the GTS Group is moving towards an integrated sustainability strategy $(\mathrm{H})$.

In the GTS Group, the pathway towards sustainability integration there was a gradual process, favored by a progressive integration in the three dimensions (technical, organizational, cognitive) and a shift from a diagnostic to an interactive use of MCSs and SCSs. During its early years, the GTS Group did not have a sustainability strategy, and sustainability issues that emerged for the growing pressures for increased health and safety performance in the industry were managed occasionally, not in a structured way. As soon as the GTS Group gained a deeper knowledge of sustainability issues, integration of the MCSs and SCSs occurred, through diagnostics at first and interactive measures later on, bringing the GTS Group to its actual Configuration G (peripheral sustainability integration). Nevertheless, the GTS Group is continuing its path towards a full integration sustainability strategy, represented by the Configuration $\mathrm{H}$. Table 3 highlights the degree of integration between MCSs and SCSs in the different integration sustainability strategies implemented in the GTS Group and the use (diagnostic or interactive) of the MCSs and SCSs.

Table 3. The Gond et al. organizational configurations in GTS Group.

\begin{tabular}{|c|c|c|c|c|c|c|c|}
\hline Type & Label & $\begin{array}{l}\text { Integration } \\
\text { of MCSs } \\
\text { and SCSs }\end{array}$ & $\begin{array}{l}\text { Use of } \\
\text { MCSs }\end{array}$ & $\begin{array}{l}\text { External Factor } \\
\text { Affecting MCSs }\end{array}$ & $\begin{array}{l}\text { Use of } \\
\text { SCSs }\end{array}$ & $\begin{array}{l}\text { External Factor } \\
\text { Affecting SCSs }\end{array}$ & Source \\
\hline A & $\begin{array}{c}\text { Dormant } \\
\text { decoupled } \\
\text { strategy }\end{array}$ & Low & Diagnostic & $\begin{array}{c}\text { Monitoring } \\
\text { compliance in rail } \\
\text { transport }\end{array}$ & Diagnostic & $\begin{array}{c}\text { Address the } \\
\text { request of } \\
\text { National Agency }\end{array}$ & $\begin{array}{c}\text { Interviews }\left({ }^{*}\right) \\
\text { Documents }\left({ }^{* *}\right)\end{array}$ \\
\hline C & $\begin{array}{l}\text { Compliance } \\
\text { driven } \\
\text { sustainability } \\
\text { strategy }\end{array}$ & Low & Interactive & $\begin{array}{l}\text { Territorial } \\
\text { extension of the } \\
\text { transportation of } \\
\text { hazardous goods }\end{array}$ & Diagnostic & $\begin{array}{l}\text { ESG mandatory } \\
\text { disclosure in } \\
\text { annual report } \\
\text { (Italian civil code) }\end{array}$ & $\begin{array}{l}\text { Interviews } \\
\text { Documents }\end{array}$ \\
\hline G & $\begin{array}{l}\text { Peripheral } \\
\text { sustainability } \\
\text { integration }\end{array}$ & High & Interactive & $\begin{array}{l}\text { Admission to the } \\
\text { "Elite" Program }\end{array}$ & Diagnostic & $\begin{array}{l}\text { Environmental } \\
\text { and social } \\
\text { outcome for } \\
\text { stakeholders }\end{array}$ & $\begin{array}{l}\text { Interviews } \\
\text { Sustainability } \\
\text { Report }\end{array}$ \\
\hline $\mathrm{H}$ & $\begin{array}{l}\text { Integrated } \\
\text { sustainability } \\
\text { strategy } \\
\text { (ongoing) }\end{array}$ & High & Interactive & $\begin{array}{l}\text { IIRC framework } \\
\text { for Integrated } \\
\text { Reporting }\end{array}$ & Interactive & $\begin{array}{l}\text { Integrated } \\
\text { information for } \\
\text { stakeholders }\end{array}$ & $\begin{array}{c}\text { Interviews } \\
\text { Integrated Report }\end{array}$ \\
\hline
\end{tabular}

$\left(^{*}\right)$ Semi-structured interviews of Founder, CEO, General Director and CFO; $\left({ }^{* *}\right)$ Documents: Annual reports and environmental management manuals. 


\section{The External Influences Affecting the Sustainability Integration Pathway of the GTS Group}

The analysis in Table 3 clearly highlights that the operating environment of the GTS Group had an influence on the GTS Group movement from one configuration to the next. The pathways to sustainability integration in strategy of the GTS Group included both systemic integration (moving from a low to a high integration level) and strategic mobilization (moving from a diagnostic to an interactive use of systems) [1]. Both cases were influenced by external and internal factors.

As regards external influences, the most famous theory used to explain the response of organizations to institutional pressures is the institutional theory, according to which institutional influences can be classified as three types: regulative, normative, and cognitive [79]. Regulative influences pressure organizations to change as laws and regulations push them toward higher standards. Normative forces are those exerted by customs, norms, expectations, and demands, while cognitive influences move organizations from the "conscious to the unconscious" as regulative and normative influences become internalized and new routines are formed.

Regulative, normative, and cognitive influences are related to different motivations that drove organizations to integrate sustainability within a corporate strategy. This behavior can be driven by the fear of penalty in a regulated context, opportunity for profit or the business case in a normative context, or a self-imposed obligation to do the right thing in a cognitive context. These motivational underpinnings are also relevant as they influence the types of relationships that organization develops with its stakeholders.

Table 4 presents a temporal reconstruction of the key events. Tables 5-7 summarize, for each stage of the GTS Group pathway towards sustainability integration, the external influences highlighted in the previous section, by classifying them into regulative, normative, and cultural influences and showing how they affected the internal corporate PMSs and the relationships that the GTS Group developed with stakeholders.

Table 4. Key events affecting the organizational configuration of the GTS Group.

\begin{tabular}{ccc}
\hline Breaking Year & Event & Configuration \\
\hline 2008 & Railway regulation & Dormant decoupled strategy \\
\hline 2011 & $\begin{array}{c}\text { Extension to the transportation of } \\
\text { hazardous goods }\end{array}$ & $\begin{array}{c}\text { Compliance driven } \\
\text { sustainability strategy }\end{array}$ \\
\hline 2014 & $\begin{array}{c}\text { Admission of the GTS Group to } \\
\text { "Elite" program }\end{array}$ & $\begin{array}{c}\text { Peripheral sustainability } \\
\text { integration }\end{array}$ \\
\hline
\end{tabular}

Table 5. External influences affecting the moving from Configuration $\mathrm{A}$ to Configuration $\mathrm{C}$ in the GTS Group.

\begin{tabular}{ccc}
\hline Regulative & Normative & Cognitive \\
\hline Railway regulation & Scarce pressure from external & $\begin{array}{c}\text { Regulative and normative } \\
\text { influences not yet internalized }\end{array}$ \\
$\begin{array}{c}\text { Strengthening of focus on audit } \\
\text { risk and process mapping }\end{array}$ & Stakeholder mapping & $\begin{array}{c}\text { Focus on sustainability was } \\
\text { not manifest }\end{array}$ \\
\hline
\end{tabular}


Table 6. External influences affecting the moving from Configuration to Configuration $G$ in the GTS Group.

\begin{tabular}{ccc}
\hline Regulative & Normative & Cognitive \\
\hline $\begin{array}{c}\text { Extension to the transportation of } \\
\text { hazardous goods }\end{array}$ & $\begin{array}{c}\text { Increasing pressure from external } \\
\text { stakeholders }\end{array}$ & $\begin{array}{c}\text { Internalization of regulative and } \\
\text { normative influences }\end{array}$ \\
$\begin{array}{c}\text { Improvement and interactive use } \\
\text { of traditional informative system }\end{array}$ & Stakeholder management & $\begin{array}{c}\text { Higher awareness of sustainability issues } \\
\text { (from the conscious to the unconscious) }\end{array}$ \\
\hline
\end{tabular}

Table 7. External influences affecting the moving from Configuration $\mathrm{G}$ to Configuration $\mathrm{H}$ in the GTS Group.

\begin{tabular}{|c|c|c|}
\hline Regulative & Normative & Cognitive \\
\hline $\begin{array}{l}\text { The GTS Group was admitted to } \\
\text { "Elite" program }\end{array}$ & $\begin{array}{l}\text { High pressure from external } \\
\text { stakeholders }\end{array}$ & New routines were formed \\
\hline $\begin{array}{l}\text { Improvement of the integration } \\
\text { between MCSs and SCSs }\end{array}$ & Stakeholder engagement & Sustainability report \\
\hline
\end{tabular}

\section{The Barriers and Enablers Affecting the Sustainability Integration Pathway of the GTS Group}

The dynamic in the use (diagnostic vs. interactive) and the integration of MCSs and SCSs in the period 2008-2015 brought the GTS Group to pass through four configurations. The Gond et al. framework [1] enabled us to identify the barriers to, and enablers of, the movement from one configuration to another, distinguishing them into technical, organizational and cognitive.

In the movement from Configuration A to Configuration C, a relevant role was played by the technical and cognitive enablers, which succeed to push the GTS Group in integrating sustainability issues into organizational strategy. Among cognitive enablers a key role was played by the GTS Group CEO, deeply aware that a "sustainability approach represents the tool able to generate economic value beyond the social and environmental value" (from a semi-structured interview with the CEO). The technical (both internal and external) and cognitive enablers were also able to neutralize the technical and cognitive barriers, namely the absence of a systematic sustainability performance measurement infrastructure and the lack of training in social and environmental issues for employees. Table 8 summarizes the main technical, organizational and cognitive enablers and barriers that favored the transition from Configuration A to Configuration C.

Table 8. Enablers and barriers affecting the moving from Configuration A to Configuration $\mathrm{C}$ in the GTS Group.

\begin{tabular}{cccc}
\hline & Enablers & Barriers \\
\hline Technical & $\begin{array}{c}\text { Effective technical } \\
\text { information systems }\end{array}$ & Technical & $\begin{array}{c}\text { No systematic sustainability } \\
\text { performance measurement } \\
\text { infrastructure }\end{array}$ \\
\hline Organizational & $\begin{array}{c}\text { Expanded structure for risk } \\
\text { analysis and process mapping }\end{array}$ & Organizational & $\begin{array}{c}\text { Lack of organizational structure for } \\
\text { sustainability related initiatives }\end{array}$ \\
\hline Cognitive & $\begin{array}{c}\text { Genuine CEO's approach } \\
\text { to sustainability }\end{array}$ & Cognitive & Lack of training in social and \\
environmental issues for employees
\end{tabular}

The consolidation of the technical, cognitive, and organizational enablers favored the integration of MCSs and SCSs and the movement from Configuration C to Configuration G.

The organizational enablers, mainly the creation of a sustainability working team, succeed in overcoming organizational barriers such as the lack of systematic performance evaluation and target 
setting. Among technical enablers, the implementation of a social and environmental cost accounting system was a tool to bridge MCSs with SCSs. The GTS Group, in relation to the circumstance to evaluate economically a contract with a key client, elaborated a model that leads to the definition of sustainable operational margins of first and second level employing the distinction of operational costs into direct and indirect costs. In turn, direct costs were divided into economic direct costs and sustainable direct costs while indirect costs were divided into economic indirect costs and sustainable indirect costs. From a cognitive point of view, the support given by the CEO to the implementation of sustainability tools also favored the moving from Configuration C to Configuration G. Table 9 summarizes the main technical, organizational and cognitive enablers and barriers that favored the transition from Configuration C to Configuration G.

Table 9. Enablers and barriers affecting the moving from Configuration $\mathrm{C}$ to Configuration $\mathrm{G}$ in the GTS Group.

\begin{tabular}{cccc}
\hline & \multicolumn{1}{c}{ Enablers } & Barriers \\
\hline Technical & $\begin{array}{c}\text { Implementation of a social and } \\
\text { environmental accounting system }\end{array}$ & Technical & $\begin{array}{c}\text { Difficulties to measure and } \\
\text { monitor sustainability risks }\end{array}$ \\
\hline Organizational & Creation of a sustainability working team & Organizational & $\begin{array}{c}\text { Lack of systematic performance } \\
\text { evaluation and target setting }\end{array}$ \\
\hline Cognitive & $\begin{array}{c}\text { GTS Group CEO supported the } \\
\text { implementation of sustainability tools }\end{array}$ & Cognitive & $\begin{array}{c}\text { Lack of training in social and } \\
\text { environmental issues } \\
\text { for employees }\end{array}$ \\
\hline
\end{tabular}

The ongoing movement from Configuration $\mathrm{G}$ to Configuration $\mathrm{H}$ was favored by an interactive use of SCSs. The shift from a diagnostic use to an interactive use of SCSs was favored by the presence of technical, organizational and cognitive enablers. These enablers in turn reinforced the technical, organizational and cognitive integration. Among the technical enablers, a sustainability planning, monitoring and budgeting system was promoted in the GTS Group. From an organizational point of view, the strengthening of the sustainability working group was a key enabler, while the cognitive dimension, universally considered by the literature as the most important one [80], was the most important factor responsible for the ongoing movement of the GTS Group from Configuration $\mathrm{H}$ to Configuration G: the attention towards sustainability was not only an issue related to the CEO, but also to the top and middle level management. Table 10 summarizes the main technical, organizational and cognitive enablers and barriers that favored the transition from configuration $\mathrm{G}$ to configuration $\mathrm{H}$.

Table 10. Enablers and barriers affecting the moving from Configuration $\mathrm{G}$ to Configuration $\mathrm{H}$ in the GTS Group.

\begin{tabular}{cccc}
\hline & Enablers & Barriers \\
\hline Technical & $\begin{array}{c}\text { Sustainability planning, monitoring and } \\
\text { budgeting system }\end{array}$ & Technical & $\begin{array}{c}\text { Difficult prediction of social and } \\
\text { environmental risks }\end{array}$ \\
\hline Organizational & $\begin{array}{c}\text { Strengthening of the sustainability } \\
\text { working team }\end{array}$ & Organizational & $\begin{array}{c}\text { Lack of systematic performance } \\
\text { evaluation and target setting }\end{array}$ \\
\hline Cognitive & $\begin{array}{c}\text { Training in sustainability reporting for } \\
\text { top and middle level management }\end{array}$ & Cognitive & $\begin{array}{c}\text { In-depth sustainability issues } \\
\text { known to few }\end{array}$ \\
\hline
\end{tabular}

\section{Conclusions}

By investigating the integration of sustainability into corporate PMSs in a real family firm operating in an environment-sensitive industry through the Gond et al. framework [1], this research provided several contributions both in theory and in practice.

Firstly, the study provides evidence that both external and internal factors were important in affecting the pathway of the organization towards sustainability integration. As regards the external 
factors, during Configuration A (dormant decoupled strategy), an important role was played the pressure exerted on the organization to belong to an industry in which an active approach towards sustainability was the norm. The GTS Group therefore ought to compare itself not to the other Apulian companies operating in the same industry and belonging to the same territory (i.e., the Apulia southern region of Italy), but to the best practices firms operating in intermodal transport. In order to gain legitimacy from its stakeholders, the GTS Group thus should refer to the praxis in terms of sustainability adopted by its direct sustainability oriented competitors. Other pressures came from the mandatory listing requirement for CSR reporting to respect to be included in the "Elite" program of the Italian stock exchange and from the more stringent sustainability related regulations in countries where the GTS Group was expanding its operations. Among internal factors that led to sustainability integration in the GTS Group's PMSs, the vital role played by the GTS Group CEO in ensuring the effective integration of sustainability by sponsoring organizational changes and providing adequate structures and personnel should be underlined. In addition, the predisposition of a long-term sustainability planning allowed the GTS Group to frame its sustainability objectives clearly. The change from an infrastructure aimed primarily at disclosing socio-environmental information to corporate stakeholders, to an infrastructure aimed at measuring the social, environmental and economic performance led to gradually updating the information system; in this way, the various departments within the company were increasingly able to provide structured data and indicators for the sustainability report.

A relevant contribution is related to the empirical confirmation that the progressive integration of SCSs was facilitated by specific enablers typical of family firms, in particular on the cognitive level, with an important role played by the GTS Group CEO who acted as a social entrepreneur. Nevertheless, the project related to sustainability required the involvement of several trained managers beyond the CEO. Between 2013 and 2015, the number of middle managers involved in meetings and gathering information and data increased and managers received a deep training in governance and reporting for sustainability, so overcoming an organizational barrier, the lack of governance for sustainability.

In the family firm analyzed, sustainability appears integrated into the firm's core business. The GTS Group really cares about understanding the stakeholders' needs, integrating the stakeholders' claims within the sustainability report and taking into consideration the stakeholders' quality judgment on the report. The GTS Group aimed to improve its sustainability performance by also improving the economic conditions of internal (employees and members) and external (local communities and suppliers) stakeholders. Moreover, the findings of the study could stimulate the discussion on how sustainability can be included in corporate PMSs and provide evidence that the Gond et al. framework could be a suitable one for a longitudinal analysis of the sustainability integration process of every kind of organization, including family firms.

One limitation of the study is that it is focused on a single case study, thereby limiting the generalization of the achieved results. Another limitation is related to the way in which dynamics is framed in the paper. Our longitudinal analysis illustrates the path of the GTS Group towards a better integration of sustainability, also analyzing the internal enablers and barriers and the external influences affecting this pathway, but it did not analyze the degree of stability of each configuration. Moreover, in this article, we illustrated whether the GTS Group responded diagnostically or interactively with MCSs and SCSs to the internal and the external influence, not considering that the reaction can occur simultaneously within the SCS and within the MCS and that the business could respond diagnostically to one solicitation and interactively to another.

Despite the research limitations, we believe that the contribution of the paper to both theory and practice is relevant, as discussed in this section. Our study adopts an empirical approach, but it is also guided by a rigorous theoretical framework, which allowed us to capture the cognitive, organizational and technical aspects of the integration of sustainability within corporate PMSs.

Future research directions could deepen the case study under investigation or widen the research scope. In the first case, further research could analyze the specific weight played by each dimension (cognitive, technical, and organizational) in promoting or hindering sustainability integration. 
A second research direction could explore which factors affect the stability of sustainability integration strategies, and which strategies are more likely to persist over time. A third research direction could explore the external dimension of SCSs, the one related to stakeholders, in order to examine how stakeholders needs are considered and implemented through SCSs. A fourth research direction could investigate how the informal elements of SCSs and MCSs affected sustainability integration in the GTS Group. Another research direction could explore the managerial sustainability orientation on the degree and mode of integration between MCSs and SCSs [10]. An additional research direction could conduct a deeper examination that considers managerial motivations, organizational-level characteristics and stakeholders relationships to explore if these factors are able to explain the reasons why organizations when faced with multiple external pressures react developing different internal resources and control systems [59]. Finally, future research could explore the role played by accounting in sustainability integration.

Widening the scope, future research could extend the research to a wider pool of companies, for instance to other companies belonging to the same industry or to other family firms operating in different industries but in the same context. This could lead to a greater understanding of the phenomenon as sustainability practices are shaped and influenced by the social-cultural context in which the organization operates. A comparative case study of companies could highlight the differences in the pathways to sustainability integration, the key processes involved and the common barriers to, and enablers of, integration.

The integration of sustainability in PMSs has been found to lead to better sustainability performance in the case organization. This means that it is vital that systems to control sustainability are not kept separate from traditional PMSs in order to embed sustainability into the core of an organization and highlight some possible implications of the research for governments, academics and organizations operating in similar industries or with similar values and beliefs (i.e., family firms). Government could reflect on the possibility of issuing reporting guidelines and regulations to support sustainability integration into the PMSs of family firms. Academics could promote better awareness and understanding of the importance of measuring and managing sustainability costs, while organizations operating in a similar context could realize the importance of overcoming cognitive barriers by increasing the awareness of sustainability benefits and of an effective stakeholder engagement for driving sustainability performance.

Acknowledgments: All sources of funding of the study should be disclosed. Please clearly indicate grants that you have received in support of your research work. Clearly state if you received funds for covering the costs to publish in open access.

Author Contributions: Stefania Veltri had the initial idea for the study. Fabio Caputo is responsible for the data collection. Stefania Veltri and Andrea Venturelli set the analysis framework. Fabio Caputo and Andrea Venturelli conducted the semi-structured interviews. All three authors wrote the paper, but their primary individual contributions are reflected as follows: Sections 4, 5 and 9 are to be ascribed to Fabio Caputo; Sections 2, 3, 8 and 10 are to be ascribed to Stefania Veltri; and Sections 1, 6 and 7 are to be ascribed to Andrea Venturelli.

Conflicts of Interest: The authors declare no conflict of interest.

\section{Appendix A. Notes}

Note 1 According to Steurer et al. [7], sustainable development, corporate sustainability, and CSR are closely related concepts focusing on stakeholder relations management but at different levels of action. Sustainable development is a guiding model at the level of society, corporate sustainability is a sustainable development model at corporate level, and CSR is a management approach for business contribution to sustainable development. As regards the differences between CSR and sustainability, CSR is more specific and depends more heavily on particular stakeholder claims than sustainability does. In addition, the two terms have a varying temporal scope since sustainability is long-term oriented, while CSR is about meeting the demands of stakeholders today in order to secure vital resources for the future company's performance. Finally, the two concepts are different as regards the historical path that drove both to address 
the integration of economic, social and environmental aspects. Sustainability started out from the environmental dimension, while CSR initially emphasized social issues like human rights and working conditions [7]. For a brief review and a graphical snapshot of the evolution of the CSR notion, see Veltri and Nardo [81].

Note 2 With use the term performance management systems (PMSs) to describe the management and control of organizational performance in a holistic manner, therefore including all aspects of organizational control related to both MCSs and SCSs. Therefore, when in the text we use the term PMSs we intend both MCSs and SCSs [22].

Note 3 Research in the area of corporate sustainability and management accounting practices cover a broad territory. It focuses on the managerial aspects of corporate sustainability practice and the research issues that relate to the implementation of sustainability at firm level. It includes sustainability management, sustainability measurement, sustainability external reporting and sustainability management control systems, all included in the sustainability accounting concept [82].

Note 4 Controls in MCSs comprise, for instance, strategic planning, budgeting, financial measurement systems, non-financial measurement systems, hybrid measurement systems, project management, and evaluation and reward. Controls in SCSs comprise, for instance, sustainability planning, environmental budgeting, sustainability budgeting, sustainable value added, environmental performance evaluation systems, material and energy flow accounting systems, sustainability performance measurement, sustainability balanced scorecard, socio-eco-efficiency analysis, environmental investment appraisal, a reward system based on multidimensional performance system [1].

Note 5 Among the studies focused on the enablers of, and barriers to, sustainability integration in PMSs, we can quote the study of Epstein and Roy [83], Riccaboni and Leone [18], Adams and Frost [58], and Perego and Hartmann [84]. The study of Epstein and Roy [83] focused on the (relevance of formal performance evaluation systems in monitoring the effectiveness of environmental strategies. The study of Riccaboni and Leone [18] described the ability of MCSs to support the execution of sustainability strategies by relying on not only formal but also informal controls. The study of Adams and Frost [58] underlines the relevance of integrating sustainability key performance indicators into corporate management processes, while the study of Perego and Hartmann [84] found that increased quantification of environmental performance measures led to an alignment with environmental strategy.

Note 6 Researchers who decide to use a case study approach must choose what type of case study to use [65]. The selection of a specific type of case study design is guided by the overall study objective. An exploratory case study should be used when the aim is to understand how a phenomenon takes place. An explanatory case study should be used when the aim is to understand why a phenomenon takes place. A descriptive case study should be adopted when the aim of the research is to convince someone that a phenomenon is relevant [70].

Note 7 The main areas investigated through the semi-structured interviews have been the following: the factors that pushed towards the implementation and disclosure of a sustainability report; the management of the process of stakeholder engagement; the activities carried out and the investments afforded for the sustainability accounting, management and reporting systems; the expected returns for the sustainable investments; the tools used to measure/evaluate the financial and economical returns of the sustainable activities undertaken. For the sake of brevity, the schemes of the semi-structured interviews are not included in the article but they are available on request. 


\section{References}

1. Gond, J.P.; Grubnic, S.; Herzig, C.; Moon, J. Configuring management control systems: Theorizing the integration of strategy and sustainability. Manag. Account. Res. 2012, 23, 205-223. [CrossRef]

2. Duygulu, E.; Ozeren, E.; Işildar, P.; Appolloni, A. The sustainable strategy for small and medium sized enterprises: The relationship between mission statements and performance. Sustainability 2016, 8, 698. [CrossRef]

3. Hahn, R.; Kühnen, M. Determinants of sustainability reporting: A review of results, trends, theory, and opportunities in an expanding field of research. J. Clean. Prod. 2013, 59, 5-21. [CrossRef]

4. Thijssens, T.; Bollen, L.; Hassink, H. Managing sustainability reporting: Many ways to publish exemplary reports. J. Clean. Prod. 2016, 136, 86-101. [CrossRef]

5. Dyllick, T.; Hockerts, K. Beyond the business case for corporate sustainability. Bus. Strategy Environ. 2002, 11, 130-141. [CrossRef]

6. WCED. Our Common Future; Oxford University Press: Oxford, UK, 1987.

7. Steurer, R.; Langer, M.E.; Konrad, A.; Martinuzzi, A. Corporations, stakeholders and sustainable development I: A theoretical exploration of business-society relations. J. Bus. Ethics 2005, 61, 263-281. [CrossRef]

8. Montiel, I. Corporate social responsibility and corporate sustainability: Separate pasts, common futures. Organ. Environ. 2008, 21, 245-269. [CrossRef]

9. Hahn, R. Integrating corporate responsibility and sustainable development. J. Glob. Resp. 2011, 2, 8-22. [CrossRef]

10. Ditillo, A.; Lisi, I.E. Exporing sustainability control systems' integration: The relevance of sustainability orientation. J. Manag. Account. Res. 2016, 28, 125-148. [CrossRef]

11. Caputo, F.; Veltri, S.; Venturelli, A. A conceptual model of forces driving the introduction of sustainability report in SMEs: Evidence from a case study. Int. Bus. Res. 2017, 10, 39-50. [CrossRef]

12. Adams, C.A.; McNicholas, P. Making a difference: Sustainability reporting, accountability and organisational change. Account. Audit. Account. J. 2007, 20, 382-402. [CrossRef]

13. Maas, K.; Crutzen, N.; Schaltegger, S. Special volume of the journal of cleaner production on 'Integrating corporate sustainability performance measurement, management control and reporting'. J Clean Prod. 2014, 65, 7-8. [CrossRef]

14. Morioka, S.N.; de Carvalho, M.M. A systematic literature review towards a conceptual framework for integrating sustainability performance into business. J. Clean. Prod. 2016, 136 Pt A, 134-146. [CrossRef]

15. Morioka, S.N.; Carvalho, M.M. Measuring sustainability in practice: Exploring the inclusion of sustainability into corporate performance systems in Brazilian case studies. J. Clean. Prod. 2016, 136 Pt A, 123-133. [CrossRef]

16. De Villiers, C.; Rouse, P.; Kerr, J. A new conceptual model of influences driving sustainability based on case evidence of the integration of corporate sustainability management control and reporting. J. Clean. Prod. 2016. [CrossRef]

17. Asif, M.; Searcy, C.; Zutshi, A.; Fisscher, O.A.M. An integrated management systems approach to corporate social responsibility. J. Clean. Prod. 2013, 56, 7-17. [CrossRef]

18. Riccaboni, A.; Leone, E.L. Implementing strategies through management control systems: The case of sustainability. Int. J. Prod. Perform. Manag. 2010, 59, 130-144. [CrossRef]

19. Naranjo-Gil, D. The role of management control systems and top teams in implementing environmental sustainability policies. Sustainability 2016, 8, 359. [CrossRef]

20. Lopez-Valeiras, E.; Gomez-Conde, J.; Naranjo-Gil, D. Sustainable innovation, management accounting and control systems, and international performance. Sustainability 2015, 7, 3479-3492. [CrossRef]

21. Schaltegger, S. Sustainability as a driver for corporate economic success: Consequences for the development of sustainability management control. Soc. Econ. 2011, 33, 15-28. [CrossRef]

22. George, R.A.; Siti-Nabiha, A.K.; Jalaludin, D.; Abdalla, Y.A. Barriers to and Enablers of Sustainability Integration in the Performance Management Systems of an Oil and Gas Company. J. Clean. Prod. 2016, 136 Pt A, 197-212. [CrossRef]

23. Battaglia, M.; Passetti, E.; Bianchi, L.; Frey, M. Managing for integration: A longitudinal analysis of management control for sustainability. J. Clean. Prod. 2016, 136 Pt A, 213-225. [CrossRef] 
24. Campopiano, G.; de Massis, A.; Cassia, L. Corporate social responsibility: A survey among SMEs in Bergamo. Procedia Soc. Behav. Sci. 2012, 62, 325-341.

25. Chrisman, J.J.; Chua, J.H.; Steier, L. Sources and consequences of distinctive familiness: An introduction. Entrep. Theory Pract. 2005, 29, 237-247. [CrossRef]

26. Sharma, P. Commentary: Familiness: Capital Stocks and Flows between Family and Business. Entrep. Theory Pract. 2008, 32, 971-977. [CrossRef]

27. Bergamaschi, M.; Randerson, K. The futures of family businesses and the development of corporate social responsibility. Futures 2014, 75, 54-65. [CrossRef]

28. Adams, J.; Taschian, A.; Shore, T. Ethics in family and non-family owned firms: An exploratory study. Fam. Bus. Rev. 1996, 9, 157-170. [CrossRef]

29. Hirigoyen, G.; Poulain-Rehm, T. The corporate social responsibility of family business: An international approach. Int. J. Financ. Stud. 2014, 2, 240-265. [CrossRef]

30. Dyer, W.G.; Whetten, D.A. Family firms and social responsibility: Preliminary evidence from the S\&P 500. Entrep. Theory Pract. 2006, 30, 785-802.

31. Berrone, P.; Cruz, C.; Gómez-Mejía, L.R.; Larraza-Kintana, M. Socioemotional wealth and corporate responses to institutional pressures: Do family-controlled firms pollute less? Admin. Sci. Quart. 2010, 55, 82-113. [CrossRef]

32. Berrone, P.; Cruz, C.; Gómez-Mejía, L.R. Socioemotional wealth in family firms: Theoretical dimensions, assessment approaches, and agenda for future research. Fam. Bus. Rev. 2012, 25, 258-279. [CrossRef]

33. Cennamo, C.; Berrone, P.; Cruz, C.; Gómez-Mejía, L.R. Socioemotional Wealth and Proactive Stakeholder Engagement: Why Family-Controlled Firms Care More About Their Stakeholders. Entrep. Theory Pract. 2012, 11, 1153-1173. [CrossRef]

34. Deniz, M.D.L.C.D.; Suárez, M.K.C. Corporate social responsibility and family business in Spain. J. Bus. Ethics 2005, 56, 27-41. [CrossRef]

35. Niehm, L.S.; Swinney, J.; Miller, N.J. Community social responsibility and its consequences for family business performance. J. Small Bus. Manag. 2008, 46, 331-350. [CrossRef]

36. Uhlaner, L.M.; van Goor-Balk, H.J.M. Family business and corporate social responsibility in a sample of Dutch firms. J. Small Bus. Enterp. Dev. 2004, 11, 186-194. [CrossRef]

37. Ding, S.; Wu, Z. Family ownership and corporate misconduct in US small firms. J. Bus. Ethics 2013, 123, 183-195. [CrossRef]

38. McGuire, J.; Dow, S.; Ibrahim, B. All in the family? Social performance and corporate governance in the family firm. J. Bus. Res. 2012, 65, 1643-1650. [CrossRef]

39. Campopiano, G.; De Massis, A. Corporate social responsibility reporting: A content analysis in family and non-family firms. J. Bus. Ethics 2015, 129, 511-534. [CrossRef]

40. Le Breton-Miller, I.; Miller, D. Family firms and practices of sustainability: A contingency view. J. Fam. Bus. Strategy 2016, 7, 26-33. [CrossRef]

41. Cowan, L.; Wright, V. An approach for analyzing the vulnerability of small family business. Systems 2016, 4, 3. [CrossRef]

42. Jørgensen, K.M. Conceptualising intellectual capital as language game and power. J. Intellect. Cap. 2006, 7, 78-92. [CrossRef]

43. De Massis, A.; Sharma, P.; Chua, J.H.; Chrisman, J.J.; Kotlar, J. State-of-the-art of family business research. In Family Business Studies: An Annotated Bibliography; De Massis, A., Sharma, P., Chua, J.H., Chrisman, J.J., Eds.; Edward Elgar: Northampton, MA, USA, 2012.

44. Del Baldo, M. Corporate Social Responsibility and Corporate Family Responsibility: Reflections in theory and practice. The case of Elica Group: 'The best Place to Work'. Econ. Res. 2013, 26, 201-224.

45. Massa, L.; Farneti, F.; Scapini, R. Developing a sustainability report in a small to medium enterprise: Process and consequences. Meditari Account. Res. 2015, 23, 62-91. [CrossRef]

46. Maas, K.; Schaltegger, S.; Crutzen, N. Integrating corporate sustainability assessment, management accounting, control, and reporting. J. Clean. Prod. 2016, 136 Pt A, 237-248. [CrossRef]

47. Zampou, E.; Karagiannaki, A.; Plitsos, S. Sustainability performance measurement in manufacturing: Integrating environmental and operational aspects. In Proceedings of the 17th EMAN Conference, Rotterdam, The Netherlands, 27-28 March 2014. 
48. Ferreira, A.; Otley, D. The design and use of performance management systems: An extended framework for analysis. Manag. Account. Res. 2009, 20, 263-282. [CrossRef]

49. Schaltegger, S.; Wagner, M. Managing sustainability performance measurement and reporting in an integrated manner. Sustainability accounting as the link between the sustainability balanced scorecard and sustainability reporting. In Sustainability Accounting and Reporting; Schaltegger, S., Bennett, M., Burritt, R., Eds.; Springer: Dordrecht, The Netherlands, 2006; pp. 681-697.

50. Ditillo, A.; Lisi, I.E. Towards a More Comprehensive Framework for Sustainability Control Systems Research. In Accounting for the Environment: More Talk and Little Progress; Freedman, M., Jaggi, B., Eds.; Emerald Group Publishing Limited: Bingley, UK, 2014; Volume 5, pp. $23-47$.

51. Arjaliès, D.; Mundy, J. The use of management control systems to manage CSR strategy: A levers of control perspective. Manag. Account. Res. 2013, 24, 284-300. [CrossRef]

52. Epstein, M.J.; Wisner, P.S. Using a balanced scorecard to implement sustainability. Environ. Qual. Manag. 2001, 11, 1-10. [CrossRef]

53. Bonacchi, M.; Rinaldi, L. Dartboards and clovers as new tools in sustainability planning and control. Bus. Strategy Environ. 2007, 16, 461-473. [CrossRef]

54. Epstein, M.J.; Wisner, P.S. Actions and measures to improve sustainability. In The Accountable Corporation; Epstein, M.J., Hanson, K.O., Eds.; Praeger Publishers: Westport, CT, USA, 2006; Volume 3, pp. 207-234.

55. Roth, H.P. Using cost management for sustainability efforts. J. Corp. Account. Financ. 2008, 19, 11-18. [CrossRef]

56. Jasch, C. Environmental and Material Flow Cost Accounting: Principles and Procedures; Springer Science: New York, NY, USA, 2009.

57. Henri, J.-F.; Journault, M. Eco-control: The influence of management control systems on environmental and economic performance. Account. Org. Soc. 2010, 35, 63-80. [CrossRef]

58. Adams, C.A.; Frost, G.R. Integrating sustainability reporting into management practices. Account. Forum 2008, 32, 288-302. [CrossRef]

59. Herremans, I.M.; Nazari, J.A. Sustainability reporting driving forces and management control systems. J. Manag. Account. Res. 2016, 28, 103-124. [CrossRef]

60. Lisi, I.E. Translating environmental motivations into performance: The role of environmental performance measurement systems. Manag. Account. Res. 2015, 29, 27-44. [CrossRef]

61. Durden, C. Towards a socially responsible management control system. Account. Audit. Account. J. 2008, 21, 671-694. [CrossRef]

62. Simons, R. Levers of Control, How Managers Use Innovative Control Systems to Drive Strategic Renewal; Harvard Business School Press: Boston, MA, USA, 1995.

63. Parker, L.D. Qualitative management accounting research, Assessing deliverables and relevance. Crit. Perspect. Account. 2012, 23, 54-70. [CrossRef]

64. Berry, A.J.; Otley, D.T. Case-based research in accounting. In The Real Life Guide to Accounting Research, a Behind-the-Scenes View of Using Qualitative Research Methods; Humphrey, C., Lee, B., Eds.; Elsevier: Amsterdam, The Netherlands, 2004; pp. 231-255.

65. Yin, R.K. Case Study Research, Design and Methods, 3rd ed.; Sage: Thousand Oaks, CA, USA, 2003.

66. Cohanier, B. What qualitative research can tell us about performance management systems. Qual. Res. Account. Manag. 2014, 11, 380-415. [CrossRef]

67. Mir, M.Z.; Rahaman, A.S. In Pursuit of Environmental Excellence: A Stakeholder Analysis of the Environmental Management Strategies and Performance of an Australian Energy Company. Account. Audit. Account. J. 2011, 24, 848-878.

68. Moilanen, S. The role of accounting in the management control system: A case study of a family-led firm. Qual. Res. Account. Manag. 2008, 5, 165-183. [CrossRef]

69. Leppäaho, T.; Plakoyiannaki, E.; Dimitratos, P. The Case Study in Family Business: An Analysis of Current Research Practices and Recommendations. Fam. Bus. Rev. 2015, 29, 159-173. [CrossRef]

70. De Massis, A.; Kotlar, J. The case study method in family business research: Guidelines for qualitative scholarship. J. Fam. Bus. Strategy 2014, 5, 15-29. [CrossRef]

71. Chua, J.H.; Chrisman, J.J.; Steier, L.P.; Rau, S.B. Sources of heterogeneity in family firms: An introduction. Entrep. Theory Pract. 2012, 36, 1103-1113. [CrossRef] 
72. Lodhia, S.; Jacobs, K. The practice turn in environmental reporting. A study into current practices in two Australian commonwealth departments. Account. Audit. Account. J. 2013, 26, 595-615. [CrossRef]

73. Ryan, B.; Scapens, R.; Theobald, M. Research Method and Methodology in Finance and Accounting; Thomson: London, UK, 2002.

74. Qu, S.Q.; Dumay, J. The qualitative research interview. Qual. Res. Account. Manag. 2011, 8, $238-264$. [CrossRef]

75. Easton, G. Critical realism in case study research. Ind. Market. Manag. 2010, 39, 118-128. [CrossRef]

76. Denzin, N.K.; Lincoln, Y.S. Introduction: The discipline and practice of qualitative research. In Handbook of Qualitative Research, 2nd ed.; Denzin, N.K., Lincoln, Y.S., Eds.; Sage Publications: Thousand Oaks, CA, USA, 2000; pp. 1-28.

77. Hoque, Z.; Cowaleski, N.A.; Gooneratne, T.A. Theoretical triangulation and pluralism in research methods in organizational and accounting research. Account. Audit. Account. J. 2013, 26, 1170-1198. [CrossRef]

78. Waddock, S.A. Fluff is not enough: Managing responsibility for corporate citizenship. Ethical Corp. 2002, 4, $12-13$.

79. Aupperle, K.E.; Carroll, A.B.; Hatfield, J.D. An empirical examination of the relationship between corporate social responsibility and profitability. Acad. Man. J. 1985, 28, 446-463. [CrossRef]

80. Jollands, S.; Akroyd, C.; Sawabe, N. Core values as a management control in the construction of 'sustainable development'. Qual. Res. Account. Manag. 2015, 12, 127-152. [CrossRef]

81. Veltri, S.; Nardo, M. The Intangible Global Report: An integrated corporate communication framework. Corp. Comm. Int. J. 2014, 18, 26-51.

82. Joshi, S.; Li, Y. What is corporate sustainability and how do firms practice it? A management accounting research perspective. J. Manag. Account. Res. 2016, 28,1-11. [CrossRef]

83. Epstein, M.J.; Roy, M.J. Implementing a corporate environmental strategy: Establishing coordination and control within multinational companies. Bus. Strategy Environ. 2007, 16, 389-403. [CrossRef]

84. Perego, P.; Hartmann, F. Aligning performance measurement systems with strategy: The case of environmental strategy. Abacus 2009, 45, 397-428. [CrossRef]

(C) 2017 by the authors. Licensee MDPI, Basel, Switzerland. This article is an open access article distributed under the terms and conditions of the Creative Commons Attribution (CC BY) license (http:/ / creativecommons.org/licenses/by/4.0/). 